〔16〕ヨウ素触媒によるビニルモノマーのカチオン重合に おけるモノマー移動定数および停止定数

(1965 年 6 月 5 日受理)

東村敏 延*・加 納 夏樹*

\begin{abstract}
要 旨 ヨウ素を触媒として $p$-メトキシスチレン $(p-\mathrm{MeOS} \mathrm{t})$, およびイソブチルビニルエーテル (IBVE) のカチオン重合を行ない, モノマー移動定数 $\left(k_{t m}\right)$ および見かけの 1 分子移動および停止定数 $\left(k_{t}{ }^{\prime}\right)$ を測定した。その結果, 次のことが見出された。i) 生長速度定数 $\left(k_{p}\right)$ と同様に, $k_{t m}$ および $k_{t}{ }^{\prime}$ は重合采の 誘電率の增加とともに增加する。ii）電子供給性の大きい置換基をもつモノマーは, $k_{p}$ も $k_{t m}$ も大きい值を 示す。iii) 触媒として強、ルイス酸を用いると， $k_{p}$ も $k_{t m}$ もともに大となる。iv) 硫酸触媒によるスチレン の重合と比較して， ヨウ素触媒による $k_{p}$ 打よび $k_{t m}$ の活性化エネルギーは小さい。これらの結果より, ウ素触媒におけるモノマー移動反応も八ロゲン化金属触媒について提出された機構と同様の機構で説明される こと, $k_{t}{ }^{\prime}$ に関与する反応は負イオンの付加よりもむしろ生長カルボニウムイオンからのプロトンの脱離反応 が支配的であることが推定された。
\end{abstract}

\section{1. 緒 言}

一般にフリーデルークラフッ触媒によるビニルモノマ 一のカチオン重合においては, 触媒から生じた対イオン が生長末端付近に存在することは良く知られている。そ のために, 触媒および溶媒の種類が変化すると, 重合速 度のみでなく生成ポリマーの分子量も著しく変化する。 そしてこの分子量の変化は，モノマー移動定数比などが 重合条件で変化するためであるということがスチレンに ついて明らかにされた1)。

その後の当研究室における一連の研究において, 触媒 の種類を一定とする場合, スチレン誘導体では系の誘電 率が増加するとモノマー移動定数比 $\left(k_{t m} / k_{p}\right)$ が減少し てポリマーの分子量が増加する ${ }^{1,2)}$ のに対して，イソブ チレンタ), ビニルェーテル4),5) などでは逆に系の誘電率が 増加すると $k_{t m} / k_{p}$ が増加してポリマーの分子量が減少 することが見出された。しかし，これらの研究では各種 の定数比が求められているのみであって, 詳細な議論を 行ならためには, 移動および停止反応の速度定数の絶対 値を知ることが必要である。

カチオン重合においてモノマー移動定数 $\left(k_{t m}\right)$ が測定 されているのは, スチレンを硫酸触媒によって塩化エチ

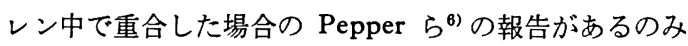
である。反応条件と $k_{t m}$ との関係は今まで報告されて いない。われわれはヨウ素を触媒とするカチオン重合に おいて，生長速度定数 $\left(k_{p}\right)$ が測定可能なことをスチレ ン誘遒体 ${ }^{7)}$ おびビニルェーテル日)について見出し，それ らの値を測定した。それゆえこれらの系において従来 の方法によって各種の定数比を求めるならば, 容易にこ れら速度定数の絶対值が求まることになる。

本報告においては主として $k_{t m}$ に及ぼす反応系の誘

* 京都大学工学部高分子化学教室(京都市左京区吉田)
電率の影響を 求めるために, 一般のフリーデルークラフ ツ触媒による重合で, 誘電率が増加すると分子量が増加 する $p$-メトキシスチレン $(p-\mathrm{MeOSt})$ と, 逆に分子量 が減少するイソブチルビニルェーテル (IBVE) について 検討を行なった。

\section{2. 実験}

2.1 試 料

$p-\mathrm{MeOSt}$ は前報》) と同様に合成し,その他のモノマー は市販品を精製して使用した。これらモノマー，溶媒お よびョウ素の精製法はすべて前報7),8) と同様であった。

2.2 操 作

重合は所定温度に保ったマイャー中のモノマー溶液に 触媒溶液を添加して開始した。一定時間重合後約 10 倍 量のメタノールに，反応液を注ぎ込むことによって反応 を停止した。沈殿したポリマーをメタノールで洗浄後, $40^{\circ} \mathrm{C}$ で減圧乾燥して精製した。ここで行なった条件で は,メタノール可溶性のポリマーは特に低モノマー濃度 の場合を除いてはほとんど生成されず，ポリマーの粘度 測定にはメタノール可溶部のポリマーは影響を与えなか った。またポリマーの分子量は重合率によって大きく変 化しなかったので，ここでは比較的高重合率 (50 80\%) のポリマーについて分子量を測定した。この研究では特 に厳密に水を除去せずに, 数 $\mathrm{m} \mathrm{mol} / l$ の水の存在で重合 を行なった。

ポリマーの分子量は $30^{\circ} \mathrm{C}$ のベンゼン溶液の極限粘度 数 $[\eta]$ より, 次式に示した粘度式を用いて求めた。

$$
\begin{aligned}
& \text { ポリスチレン6) } \\
& {[\eta]=4.37 \times 10^{-4} \bar{M}^{0.66}} \\
& \text { ポリパラメトキシスチレン2) } \\
& {[\eta]=1.66 \times 10^{-4} \bar{M}^{0.65}}
\end{aligned}
$$


ポリイソブチルビニルエーテル5)

$$
[\eta]=7.55 \times 10^{-5} \bar{M}^{0.75}
$$

それゆえ,ここで $[\eta]$ の測定から求めた分子量は正確 な数平均分子量でなく, むしろ重量平均分子量に近い值 を示すことになる。しかし，一般にカチオン重合で得た ポリマーでは $\bar{M}_{w} / \bar{M}_{n}$ の值は 2 に近いことが知られて おり お $^{97}$ 一定のモノマーについて重合条件による分子量 の相対的な変化を知る上にはさしつかえないのでここ では (1) (3) 式から算出した分子量を用いて，種々の速 度定数比を求めた。

\section{3. 結 果}

\section{1 移動および停止定数の測定法}

ポリマーの分子量を規定する反応として次の素反応を 板定した。

生長反応:

$$
\mathrm{M}_{r}^{*}+\mathrm{M} \stackrel{k_{p}}{\longrightarrow} \mathrm{M}_{r+1} *
$$

1 分子停止または移動反応：

$$
\mathrm{M}_{n}{ }^{*} \stackrel{k_{t}}{\longrightarrow} \mathrm{P}_{n}
$$

2 分子停止または移動反応：

$$
\mathrm{M}_{n}^{*}+\mathrm{X} \stackrel{k_{t X}}{\longrightarrow} \mathrm{P}_{n}+\mathrm{X}^{\prime}
$$

モノマー移動反応：

$$
\mathrm{M}_{n}{ }^{*}+\mathrm{M} \stackrel{k_{t m}}{\longrightarrow} \mathrm{P}_{n}+\mathrm{M}_{1} *
$$

ただし，ここで X は系中の不純物を意味するものとす る。上式から (7) および (8) 式が導かれるが，われわれ は $k_{t}$ と $k_{t X}$ を区別することができないので, ここでは 簡単に $\left(8^{\prime}\right)$ 式の形で $1 / \bar{P}$ と $1 /[\mathrm{M}]$ のプロットを行な った。以下に述べる実験結果から見られるように，1/P

$$
\begin{gathered}
\bar{P}_{n}=\frac{k_{p}[\mathrm{M}]\left[\mathrm{M}^{*}\right]}{k_{t}\left[\mathrm{M}^{*}\right]+k_{t X}[\mathrm{X}]\left[\mathrm{M}^{*}\right]+k_{t m}[\mathrm{M}]\left[\mathrm{M}^{*}\right]} \\
\frac{1}{\bar{P}_{n}}=\frac{k_{t}+k_{t X}[\mathrm{X}]}{k_{p}} \frac{1}{[\mathrm{M}]}+\frac{k_{t m}}{k_{p}} \\
=\frac{k_{t}^{\prime}}{k_{p}} \frac{1}{[\mathrm{M}]}+\frac{k_{t m}}{k_{p}}
\end{gathered}
$$

と $1 /[\mathrm{M}]$ は直線関係を示すことから，この取扱の妥当 なことが示される。また, 直線の切片と勾配から $k_{t m} / k_{p}$ および $k_{\ell}^{\prime} / k_{p}$ の值が求められる。

前報までに同じ重合条件での $k_{p}$ の值が求められてい るので, ここで求めた $k_{t m} / k_{p}$ および $k_{t}{ }^{\prime} \mid k_{p} に k_{p}$ の
值を乗ずることによって， $k_{t m}$ および $k_{t}^{\prime}$ をそれぞれ求 めることができる。

\section{2 各種重合条件での移動および停止定数}

ヨウ素を触媒として $p$-MeOSt および IBVEを塩化 エチレンおよび四塩化炭素中で重合せしめ，モノマー濃 度と生成ポリマーの分子量との関保を求めた。得られた 結果を $\left(8^{\prime}\right)$ 式に従ってプロットすると, Fig. 1 3 に示 すように直線関係が得られた。これらの図から明らかな よ5に, $p-\mathrm{MeOSt}$ は四塩化炭素中よりも極性溶媒であ

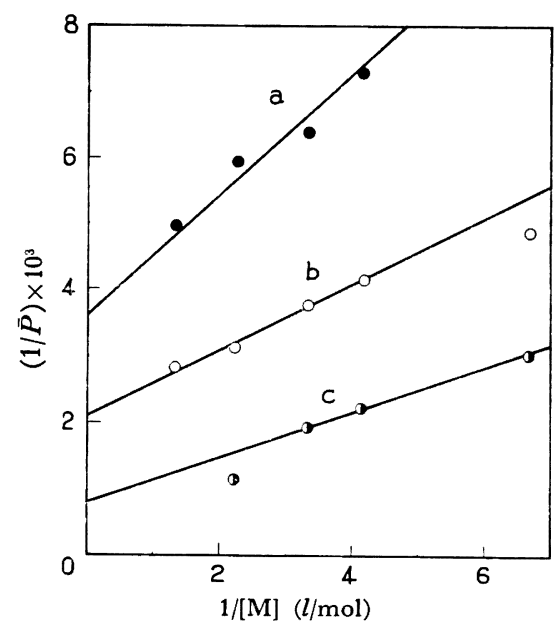

Polymerization temperature $\left({ }^{\circ} \mathrm{C}\right)$ : a $(\mathcal{O}) 50.0$, b (O) 30.0, c (O) $3.0,\left[I_{2}\right] 0.2 \sim 0.5 \mathrm{~m} \mathrm{~mol} / l$

Fig. 1. Plots of $1 / \bar{P}$ against $1 /[\mathrm{M}]$ in polymerization of $p$-methoxystyrene catalyzed by $I_{2}$ in $\left(\mathrm{CH}_{2} \mathrm{Cl}\right)_{2}$.

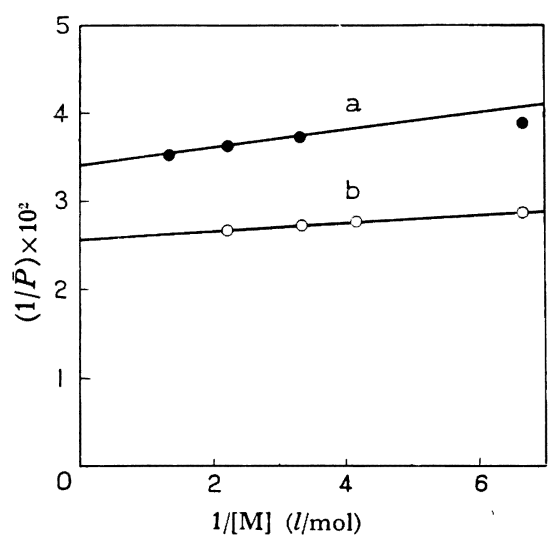

Polymerization temperature $\left({ }^{\circ} \mathrm{C}\right)$ : a (O) 50.0 , b (O) $30.0,\left[\mathrm{I}_{2}\right] 10 \sim 20 \mathrm{~m} \mathrm{~mol} / \mathrm{l}$

Fig. 2. Plots of $1 / \bar{P}$ against $1 /[\mathrm{M}]$ in polymerization of $p$-methoxystyrene catalyzed by $\mathrm{I}_{2}$ in $\mathrm{CCl}_{4}$. 


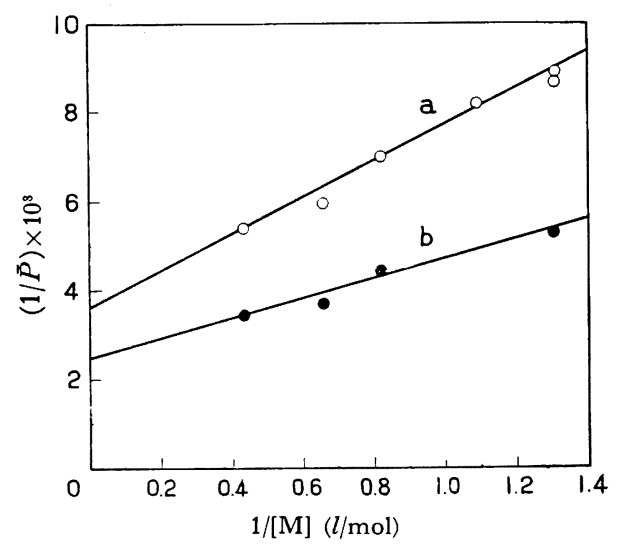

Solvent : a (O) $\left(\mathrm{CH}_{2} \mathrm{Cl}\right)_{2}, \mathrm{~b}(\bullet) \mathrm{CCl}_{4}$ $\left[\mathrm{I}_{2}\right]$

$0.2 \mathrm{~m} \mathrm{~mol} / l$ in $\left(\mathrm{CH}_{2} \mathrm{Cl}\right)_{2},>0.2 \mathrm{~m} \mathrm{~mol} / l$ in $\mathrm{CCl}_{4}$

Fig. 3. Plots of $1 / \bar{P}$ against $1 /[\mathrm{M}]$ in polymerization of isobutyl vinyl ether catalyzed by $\mathrm{I}_{2}$ at $30^{\circ} \mathrm{C}$.

る塩化ェチレン中での方が大きい分子量のポリマーが得 られるのに対して, IBVE では逆に無極性溶媒である四 塩化炭素の方が大きい分子量のポリマーが得られている ことに注目すべきである。

比較のために塩化ェチレン中でスチレンの重合を行な い, その結果を Fig. 4 に示した。これらの図より求め た速度定数比をまとめて, $30^{\circ} \mathrm{C}$ の值を Table 1 に示し た。

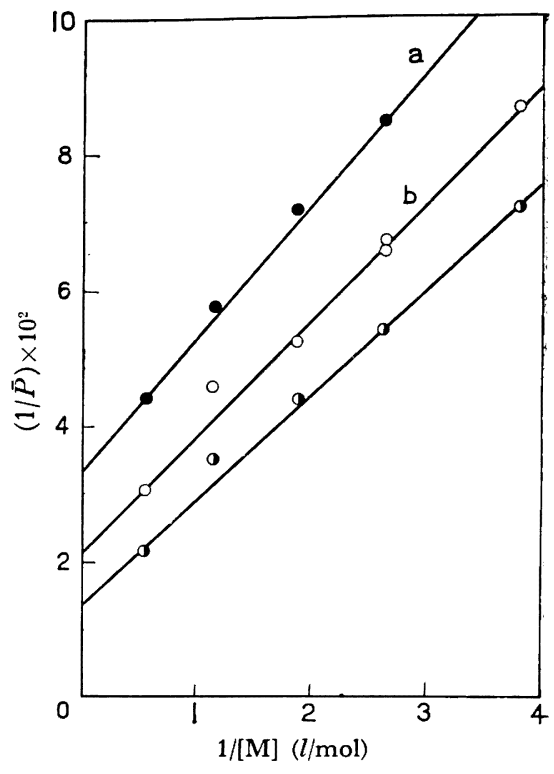

Polymerization temperature $\left({ }^{\circ} \mathrm{C}\right):$ a $(-) 46.2$, b (O) 29.9, c (O) $8.4,\left[\mathrm{I}_{2}\right] 0.070 \sim 0.120 \mathrm{~mol} / \mathrm{l}$

Fig. 4. Plots of $1 / \bar{P}$ against $1 /[\mathrm{M}]$ in polymerization of styrene catalyzed by $\mathrm{I}_{2}$ in $\left(\mathrm{CH}_{2} \mathrm{Cl}\right)_{2}$.

Table 1 に示したこれらの定数比と, 別に求められて いる $k_{p}$ の值から求めた $k_{t m}$ と $k_{t}{ }^{\prime}$ の值を Table 2 に まとめて示した。モノマーの種類に無関倸に，系の誘電 率が増加するとこれらすべての定数が増加していること

Table 1. Monomer transfer and termination constant ratio in the polymerization of styrene, $p$-methoxystyrene and isobutyl vinyl ether catalyzed by $\mathrm{I}_{2}$ at $30^{\circ} \mathrm{C}$.

\begin{tabular}{c|c|c|c|c}
\hline \multirow{2}{*}{ Solvent $\rightarrow$} & \multicolumn{2}{|r}{$\mathrm{CCl}_{4}$} & \multicolumn{2}{|c}{$\left(\mathrm{CH}_{2} \mathrm{Cl}\right)_{2}$} \\
\cline { 2 - 5 } Monomer $\downarrow$ & $k_{t m} / k_{p}$ & $k_{t}^{\prime} / k_{p}$ & $k_{t m} / k_{p}$ & $k_{t}^{\prime} / k_{p}$ \\
\hline Styrene & - & - & $2.1 \times 10^{-2}$ & $1.8 \times 10^{-2}$ \\
p-MeOSt & $2.6 \times 10^{-2}$ & $4.4 \times 10^{-4}$ & $2.1 \times 10^{-3}$ & $4.9 \times 10^{-4}$ \\
IBVE & $2.5 \times 10^{-3}$ & $2.2 \times 10^{-8}$ & $3.6 \times 10^{-3}$ & $4.1 \times 10^{-4}$ \\
\hline
\end{tabular}

Table 2. Rate constants in the polymerization of styrene, $p$-methoxystyrene and isobutyl vinyl ether catalyzed by $\mathrm{I}_{2}$ at $30^{\circ} \mathrm{C}$.

\begin{tabular}{|c|c|c|c|c|c|c|}
\hline \multirow[b]{2}{*}{ Monomer $\downarrow$} & \multicolumn{3}{|c|}{$\mathrm{CCl}_{4}$} & \multicolumn{3}{|c|}{$\left(\mathrm{CH}_{2} \mathrm{Cl}\right)_{2}$} \\
\hline & $\begin{array}{c}k_{p} \\
\left(l / \mathrm{mol}^{\prime} \cdot \min \right)\end{array}$ & $\begin{array}{c}k_{t m} \\
(l / \mathrm{mol} \cdot \min )\end{array}$ & $\begin{array}{c}k_{t}^{\prime} \\
\left(\min ^{-1}\right)\end{array}$ & $\stackrel{k_{p}}{(l / \mathrm{mol} \cdot \min )}$ & $\begin{array}{c}k_{t m} \\
(l / \mathrm{mol} \cdot \mathrm{min})\end{array}$ & $\begin{array}{c}k_{t}{ }^{\prime} \\
\left(\min ^{-1}\right)\end{array}$ \\
\hline Styrene & - & - & - & 0.22 & $0.46 \times 10^{-2}$ & $0.40 \times 10^{-2}$ \\
\hline$p-\mathrm{MeOSt}$ & 7.4 & 0.19 & $0.33 \times 10^{-2}$ & 850 & 1.8 & 0.42 \\
\hline IBVE & 5.0 & $1.3 \times 10^{-2}$ & $1.1 \times 10^{-2}$ & 390 & 1.4 & 0.16 \\
\hline
\end{tabular}


ヨウ素触媒によるビニルモノマーのカチオン重合におけるモノマー移動定数およぴ停止定数

Table 3. Activation energy of monomer transfer constant in the polymerization of (kcal/mol unit) styrene and $p$-methoxystyrene catalyzed by $\mathrm{I}_{2}$.

\begin{tabular}{l|l|l|l|l}
\hline \hline Monomer & Solvent & $E_{p}-E_{t m}$ & $E_{p}$ & $E_{t m}$ \\
\hline Styrene & $\left(\mathrm{CH}_{2} \mathrm{Cl}\right)_{2}$ & $-4.5 \pm 0.7$ & $6.0 \sim 6.5^{10}$ & $9.8 \sim 11.7$ \\
$p$-MeOSt & $\left(\mathrm{CH}_{2} \mathrm{Cl}\right)_{2}$ & $-5.6 \pm 0.5$ & $3.2 \sim 3.8^{11}$ & $8.3 \sim 9.9$ \\
$p$-MeOSt & $\mathrm{CCl}_{4}$ & -2.9 & $4.5 \sim 5.5^{12}$ & $7.4 \sim 8.4$ \\
\hline
\end{tabular}

がわかる。

一方, Fig. 1, 2 および 4 からモノマー移動定数比の 活性化エネルギーが求められる。すなわち， $k_{t m} / k_{p}$ に ついての Arrhenius plot を行なうと $E_{t m}-E_{p}$ の値が 求まる。前報までに求められている $E_{p}$ の值 ${ }^{10)}$-12) を考 慮して $E_{t m}$ が求められた。その值を Table 3 に示す。

\section{4. 考察}

上述のようにヨウ素を触媒とする種々の重合系に対し て, モノマー移動定数 $\left(k_{t m}\right)$ と見かけの停止速度定数 $\left(k_{t}{ }^{\prime}\right)$ を求めることができた。しかし， $k_{t}{ }^{\prime}$ は $(8)$ および $\left(8^{\prime}\right)$ 式から見られるように, 1 分子停止反応のみでなく 系中の不純物による停止または移動反応を含む複雑な項 である。本研究においては系中の不純物を完全に除くこ

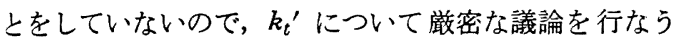
ことは危険であり，ここでは定性的な議論のみを行なう ことにする。

本研究で注意すべきことは, 生成ポリマーの分子量の 活性末端濃度依存性である。ここで行なっている範囲の 触媒濃度変化では分子量はほとんど差がなく，このこと は (7) 式から認められるところと一致する。また, 重合 系の誘電率が変化すると前報 ${ }^{12)}$ で述べたように $k_{p}$ が 著しく変化するから，モノマー濃度の増減によって系の 誘電率が変化することをさけねばならない。それゆえ, ここでは比較的低モノマー濃度の範囲での実験を行なっ た。

Table 1 より見られるように, ヨウ素触媒においても 他の八ロゲン化金属化合物と同様に, $p$-MeOSt の重合 では溶媒の誘電率が増加すると $k_{t m} / k_{p}$ は減少して大き い分子量のポリマーを与え, IBVE では全く逆の傾向を 示した。速度定数比の誘電率による変化はこのようにモ ノマーの種類によって異なるが, Table 2 からわかるよ らに，それぞれの素反応の絶対速度定数は大略次のよう に変化しているということができる。

1) $k_{p}, k_{t m}$ および $k_{t}{ }^{\prime}$ は重合系の誘電率の増加とと もに増加する。

2）電子供給性の大きい置換基をもつモノマーは，だ ひたい $k_{p}$ も $k_{t m}$ も大きい值を示す。

一方, スチレンの塩化ェチレン中の $\mathrm{SnCl}_{\text {、による重 }}$
合では $k_{p}$ は $25.2 \mathrm{l} / \mathrm{mol} \cdot \mathrm{min}$ であり ${ }^{13)}$, 同一条件での $k_{t m} / k_{p}$ の值は $0.43 \times 10^{-2}$ であった ${ }^{14)}$ 。両者の反忍系で の不純物の量は同一でないので，厳密には比較できない が, $k_{t m}$ として約 $0.11 \mathrm{~mol} / l \cdot \mathrm{min}$ なる值が得られる。 この值を Table 2 のスチレンーヨウ素系の值と比較して 次のことがいえる。

3）触媒として強いルイス酸を用いると $k_{p}$ も $k_{t m}$ も ともに増加する。

以上のまとめからわかるように, 生長末端のイオン対 が解離しやすい条件ほど, $k_{p}$ も $k_{t m}$ も増加するという ことができる。したがって重合に用いる溶媒または触媒 の種類を変えることによって生成ポリマーの分子量が増 減するのは,これらの変化がもたらす $k_{t m}$ または $k_{t}^{\prime}$ の 増加率が， $k_{p}$ のそれを上まわるかどうかという相対的 問題にすぎないことになる。

モノマー移動反応について考えてみると， $p$ - MeOSt では溶媒が 四塩化炭素から塩化ェチレンに変化すると, $k_{p}$ は 50 倍増すのに対して $k_{t m}$ は数倍増すにすぎない。 他方, IBVE では同様の溶媒の変化に対して $k_{p}$ も $k_{t m}$ もともに 50 倍以上増加する。普通のイオン反応で考え られているように，遊離イオンの方がイオン対より反応 性が大きいとするならば, $p$-MeOSt のモノマー移動反 応はイオンの解離が律速段階にならないイオン対のまま の反応ということができる。

Kennedy ら ${ }^{15)}$ はイソブテンのカチオン重合に掠いて, 生長反応ではモノマーの付加するためにイオン対の解離 を必要とするが，モノマー移動反応ではイオン対の解離 を必要としないことを報告している。ヨウ素による $p$ $\mathrm{MeOSt}$ の重合においても同様の関係が存在するのであ ろう。この推定は $p$-MeOSt のモノマー移動反応の律速 段階が (9) 式であるとする他のフリーデルークラフッ触 媒による重合機構 ${ }^{2}$ と矛盾しない。一方，IBVE では生<smiles>C=Cc1ccc(OC)c(CCCCCC)c1</smiles> 
長反応もモノマー移動反応もともにカルボニウムイオン が，それぞれモノマーの $\beta$-炭素およびェーテル酸素を 攻撃する段階が律速段階となっていることが予想され, これも $\mathrm{BF}_{3} \cdot \mathrm{O}\left(\mathrm{C}_{2} \mathrm{H}_{5}\right)_{2}$ 触媒について提出された機構(5) と 一致する。

硫酸触媒によるスチレンの重合では, $k_{p}$ および $k_{t m}$ の活性化エネルギーとして，それぞれ $8.5 \mathrm{kcal} / \mathrm{mol}$ お よび $16 \mathrm{kcal} / \mathrm{mol}$ という值が報告されている 3 より見られるように，ヨウ素を触媒とするこれらの值 は硫酸触媒に比して小さい。反応機構との関連において 議論を行ならことはできないので，ここでは実験事実に ついて述べるにとどめた。

一方, 停止反応については，i）生長末端と塩基性物質 (対アニオンあるいは采中の不純物) との結合, および ii) カルボニウムイオンからのプロトンの放出の二つの機構 が考えられる。本研究で求めた $k_{t}{ }^{\prime}$ の值は前述のように 単一の素反応に対する値でないが，反応速度に対する誘 電率の影響を考えると機構 i) は否定される。すなわち, 異符号のイオン間の反応, またはイオンと中性分子との 反応の速度は, 反応系の誘電率の増加とともに減少する ことが知られている(16)。しかし, 実験結果は $k_{t}{ }^{\prime}$ が反応 采の誘電率の増加とともに増加しているから, 上述の結 論が得られるわけである。それゆえ $k_{t}{ }^{\prime}$ に関与する反応 は機構 ii）が支配的であると考えられる。事実, この過 程はプロトンが脱離して荷電の解離を含むため, 誘電率 の高い采で促進されることは容易に推定されるところで ある。

付 記：本研究を行ならにあたり,ご指導をいただいた岡村 誠三教授に感謝する。

\section{文献}

1) 桜田 洋, 東村敏延, 岡村誠三: 工化, 61, 1640 (1958)

2) Y. Imanishi, S. Matsushita, T. Higashimura, S. Okamura: Makromol. Chem., 70, 68(1964)

3) 今西幸男, 東村敏唌, 岡村誠三：高化，18, 333 (1961)

4) 今西幸男, 東村敏延, 岡村誠三: 高化, 19, 154 (1962)

5) 今西幸男, 中山博之, 東村敏延, 岡村誠三: 高化, 19, 565 (1962)

6) M. J. Hayes, D. C. Pepper: Proc. Roy. Soc., A263, 63(1961)

7) S. Okamura, N. Kanoh, T. Higashimura : Makromol. Chem., 47, 19(1961)

8) S. Okamura, N. Kanoh, T. Higashimura: Makromol. Chem., 47, 35(1961)

9）東村敏延, 今西幸男, 福島忠久, 今西淑子, 岡村誠 三: 高化, 22，241(1965)

10) N. Kanoh, T. Higashimura, S. Okamura : Makromol. Chem., 56, 65(1962)

11）加納夏樹： 未発表データ

12) N. Kanoh, K. Ikeda, A. Gotoh, T. Higashimura, S. Okamura : Makromol. Chem. 86, 200 (1965)

13）加納夏樹, 東村敏延, 岡村誠三：高化，19, 181 (1962)

14）岡村誠三, 東村敏延：高化，13，262(1956)

15) J. P. Kennedy, R. M. Thomas : J. Polymer Sci., 49, 189(1961)

16) S. Glasstone, K. J. Laidler, H. Eyring: “The Theory of Rate Processes". Chapter 8, 400 (1941) McGraw-Hill

\title{
Studies on Monomer Transfer and Termination Constants in the Cationic Polymerization of Vinyl Monomers Catalyzed by Iodine
}

\author{
By Toshinobu Higashimura* and Natsuki Kanoh*
}

\begin{abstract}
p-Methoxystyrene and isobutyl vinyl ether have been polymerized by using iodine as a catalyst. Monomer transfer constant $\left(k_{t m}\right)$ and apparent unimolecular transfer or termination constant $\left(k_{t}{ }^{\prime}\right)$ were determined in carbon tetrachloride and ethylene chloride solution. Results were summarized as follows; 1) $k_{t m}$ and $k_{t}{ }^{\prime}$ as well as $k_{p}$ increased with increasing polarity of the solvent. 2) Monomer with strong electron-donating groups showed large $k_{t m}$ and $k_{p}$. 3) With strong Lewis acid catalyst, $k_{p}$ and $k_{t m}$ increased. 4) The activation energy of $k_{p}$ and $k_{t m}$ using iodine catalyst was smaller than that using sulfuric acid catalyst. These results indicate that monomer transfer in cationic polymerization using iodine is similar to that using conventional metal halides. The abstraction of proton from a growing chain end is more important than recombination of the growing chain with the counter anion for the reaction related to $k_{t}^{\prime}$.
\end{abstract}

* Department of Polymer Chemistry, Kyoto'University (Yoshida, Sakyo-ku, Kyoto) 